\title{
Goal into own goal? Reaction to sanctions against Russia in the Russian and German media
}

\author{
Olga Mikhina ${ }^{1, *}$, Artem Mikhin ${ }^{1}$, and Aleksandra Osipova ${ }^{1}$ \\ ${ }^{1}$ Nosov Magnitogorsk State Technical University, 455000, 38 Lenin str., Magnitogorsk, Russia
}

\begin{abstract}
The problem raised in the paper is very acute. The sanctions currently applied by Western countries towards Russia are unprecedented. Germany actively supports the sanctions policy, being influenced by the United States. The accession of the Crimea to Russia, the support of the liberation struggle of the rebels in the Lugansk and Donetsk People's Republics is only an excuse for political and economic pressure on the Russian Federation executed by the North Atlantic Alliance in connection with its growing influence on the international arena. This pressure has become the subject of extensive discussions in the media. Who benefits from anti-Russian sanctions and who will suffer the main damage from their consequences? The Kremlin has traditionally been for the Bundestag a reliable trading partner for import and export tuernover, in which a significant share is represented by energy resources from Russia that are strategically important for the German economy. The apparent unwillingness of business communities to participate in the unfavorable policy of trade restrictions affects the domestic political situation in Germany. Ordinary German citizens do not like the reduction of tens of thousands of jobs and the closure of enterprises. These processes are reflected in the Russian and German press, which served as material for this article. The analysis is based on the anthropocentric and sociocultural approaches used when analyzing political discourse and the linguistic picture of the world.
\end{abstract}

In the official documents of the European Union, the term sanctions is interpreted as an instrument for establishing and maintaining peace, reaction to violations of human rights and international law. Their purpose is to influence the policy and strategy of the country, organization or individuals who have the ability to resolve conflict situations. Sanctions should not be punitive in nature, negatively impact the broad masses of the population of the country that fells under them [1].

Germany is an active participant in the process of sanctions influence on Russia in connection with the settlement of the conflict in Ukraine. It is obvious to all interested parties that this position is compelled for Germany, and the leading EU country takes it

\footnotetext{
* Corresponding author: lga-sinyaeva@ yandex.ru
} 
being under the pressure of the US administration. The Kremlin is a traditionally reliable trade partner for the Bundestag with a very substantial import-export turnover. A significant part of it is represented by Russian energy resources strategically important for the German economy. Nevertheless, the commitments made by Germany in common with the US foreign policy aimed at curbing the growing influence of Russia, have a negative impact on the Russian-German relations. This state of affairs, of course, provokes a reaction from politicians, representatives of business communities and ordinary citizens of both countries. It is reflected in the media, where the sanction rhetoric has become a constant theme. In this paper, making a brief overview of publications of this orientation, we do not evaluate the Russian and German media in terms of their bias or independence from the politics.

How are the sanctions principles declared in the EU documents implemented? Are they at the present stage only an instrument of unfair competition, a way to achieve superiority and satisfy the imperial ambitions of the key players in international politics? Let us make a brief digression into the history of the matter.

In March 2014, after accession of the Crimea to Russia, which was perceived in the West as an annexation, the USA, Australia, Canada, New Zealand and the European Union applied the first package of sanctions against the Russian Federation. It provided for limiting contacts with a number of Russian organizations and freezing the assets of persons who took part in actions aimed at violating the "integrity of Ukraine". Also persons included in the "black lists" were banned to travel to foreign countries [2: 90].

From the point of view of the Western partners, the Minsk agreements were not implemented by the Russian side, and in this connection in September 2014 the sanctions were tightened. The new package was directed against state banks, the import and export of military equipment, as well as the oil and gas industry of the Russian Federation. According to the news portal tagesschau.de, the EU countries wanted to induce President V. Putin with these countermeasures to use his influence on pro-Russian separatists to settle the conflict in Eastern Ukraine. The Kremlin considered these actions unjustified [3]. In particular, the Chairman of the Eastern Committee of the German Economy E. Cordes noted: Die Art und Weise, wie die Sanktionen von der EU nun ohne große Debatte um sechs Monate verlängert werden, ist enttäuschend / The manner to extend EU sanctions without much discussion for 6 months is disappointing. He believes that the Russian government sent signals of de-escalation, and the heads of the EU member states did not notice that Kiev should implement the Minsk agreements as well: ... damit wird erneut die Chance verpasst, ein Stück auf Russain zuzugehen und so wieder zu einer positiven Dynamik in den gegenseitigen Beziehungen zu kommen / This again misses the chance to get a little closer to Russia and establish a positive dynamic in the relationship. In addition, it is obvious that it is in the interests of both parties to urgently begin to withdraw from the sanctions /... ist doch offensichtlich, dass wir im Interesse aller Seiten dringend einen Einstieg in den Ausstieg aus den Sanktionen brauchen [4].

A number of German publications critically comment on the sanctions policy towards Russia and tries to analyze its causes. Thus, the Foundation for Economy and Politics jointly with the German Institute for International Policy and Security published a brochure by S. Fischer entitled "EU-Sanktionen gegen Russland. Ziele, Wirkung und weiterer Umgang"/ EU sanctions against Russia. Goals, influence and further communication. As the author notes, in recent years sanctions have become a usual tool of the EU's foreign policy. But sanctions against Russia are unprecedented. The European Parliament has developed a three-stage mechanism: 1) diplomatic sanctions; 2) sanctions aimed at individuals (prohibition of issuing visas and freezing of accounts in the EU); 3) sectoral economic sanctions. Many members of the National Security Council, leading representatives of secret services, the president of the Chechen Republic, R. Kadyrov and 
the governor of the Krasnodar Territory A. Tkachev, the Defense Minister and the head of the Russian General Staff found themselves in the "black list".

The crash of the Malaysian Boeing 777 aircraft near the city of Shakhtyorsk, the Donetsk region, which was shot down, according to Western specialists, by the militiamen of the "self-proclaimed republics", had a decisive influence on the EU member states that had been skeptical in the issue of sanctions before that. From the point of view of S. Fisher, the EU sanction policy is coordinated with the US government. Even previously the United States sanctions were targeted at Russian oligarchs in Putin surroundings / Die Sanktionspolitik der EU ist eng mit jener der US-Regierung abgestimmt. Die Sanktionen der USA zielten schon früher und umfassender auf russische Oligarchen in Putins Umgebung. The author believes that the Barack Obama Administration was under strong pressure from Republicans and Democrats in the Senate and the House of Representatives, demanding a more severe reaction to the supply of weapons from Moscow to the rebels, and the main purpose of the restrictions was to change Russian political leadership (Ablösung der russischen politischen Führung). In this light, the policy of sanctions becomes an instrument of a wide-spread Western strategy to weaken Russia. I Auch die Sanktionspolitik wird in dieser" Sicht zu einem Instrument einer breit angelegten westlichen Strategie umgedeutet, die darauf abziele, Russland zu schwächen [1].

In 2014, Russian citizens, led by the leaders of various political parties, responded to the sanctions war with numerous rallies "For decent work in the world and without sanctions!". Activists and supporters of the Kemerovo regional branch of the party "PATRIOTS OF RUSSIA" headed by Yu. Skvortsov took part in the rally that took place in the capital of Kuzbass within the framework of the World Day of Action "For Decent Work" <...> The event was held under the slogans "For decent and peaceful work without sanctions!", "The War of Sanctions is the Undermining of the Incomes and Employment of All Workers!", "We will support the residents of Donetsk and Lugansk!" [5]; We are with the Communist Party of the Russian Federation and the Russian working class! We condemn the imposition of economic sanctions against Russia ([6]); On May 1, 2015, events of various political forces were traditionally held in Russia. All parliamentary parties, except the Socialist-Revolutionaries, focused on the themes of international politics and the situation in Ukraine: "We oppose sanctions, restore economic ties between countries, for a ceasefire and stop the civil war in Ukraine" ([7]). Some slogans were openly provocative, for example: Hey, USA, pick up the slobber! [8]. In the German media, it was possible to meet the slogan Schluss mit der Unterwürfigkeit gegenüber den USA! / End of servility to the USA! The partnership between Germany and the United States is of great importance, but Berlin and Washington clearly disagree in the issues of security and protection of freedoms that undermine this partnership. The German weekly Der Spiegel wrote about the uneasy relations between the United States and Germany. According to the position of the publication, Berlin should show more independence in foreign policy, even if it makes it less convenient partner for Washington. The journal published the results of a survey of public opinion: almost $60 \%$ of Germans want to distance themselves from the United States in international affairs [9: 270-271].

Russian political scientists note that sanctions only make Russia becoming stronger in its positions: The funniest thing is that the sanctioners cannot really formulate what Russia should do to limit the restrictions. Return the Crimea to Ukraine? But even Merkel does not believe in the reality of such an event. Observe the Minsk agreements? But the question is: why sanctions are not applied against Ukraine, if President Poroshenko openly stated that he is not going to implement the agreements reached in the Belarus capital. Well, Syria is simply a matter of powerlessness to change Russia's policy. ... We are being sanctioned, and we are getting stronger [10]; Sanctions made us stronger! (From an interview with the Director of the Economic Development Department of the Ministry of Economic 
Development of the Russian Federation [11]). Moscow perceives the Western sanction regime as a product of the one-sidedness of American foreign policy. According to most Russians, Washington and the EU leaders have imposed a policy on their own interests to the rest of the European Union, and the US leadership in this process reveals the political weakness of Europe.

Unexpected was the reaction of the Russians, who fell into personal restrictive lists. They treat sanctions as an act of solidarity with the Motherland and participation in the political course of the current government. S. Fischer refers to the site kommersant.ru of 01.30.2015 and quotes the Russian businessman A. Rotenberg, who speaks of sanctions as an opportunity to contribute to the development of the country / um "seinen Beitrag zur Entwicklung des Landes" zu leisten. The author cites the independent survey of the Levada Institute, from which it follows that $67 \%$ of respondents consider the hostile attitude and desire to use the moment to put pressure on Russia as the main motive of the West's policy towards the Crimea and Eastern Ukraine / das Hauptmotiv der Politik des Westens im Hinblick auf die Krim und Die Ostukraine in seiner feindseligen Haltung und dem Bestreben, den Moment zu nutzen, um Druck auf Russland auszuïben [1].

The consequences of sanctions affected not only Russia but also many European states. In response, Moscow imposed restrictions on the import of Western agricultural products. In 2014, only the German economy lost about 8.5 billion euros from the export to Russia. Therefore, German entrepreneurs were disappointed with the actions of the EU ([12]). On the eastern territories of Germany, according to some estimates, about 30 thousand jobs directly depend on the trade with Russia. In November 2017, in an interview with Izvestia, M. Fronmeier, a deputy of the "Alternative for Germany" party, stated that "according to German enterprises, Germany has already lost more than 42,000 jobs because of sanctions, and some companies went bankrupt. It is obvious that sanctions are detrimental to the German economy, and they impede the improvement of the well-being of our citizens" [13]. The party "Alternative for Germany" is not the first political force in the EU, advocating the lifting of sanctions against Moscow. Thus, the Parliament of Cyprus voted in favor of a resolution to lift sanctions against Russia; earlier four Italian regions voted for a resolution calling for overcoming the sanction regime and restoring full relations with Russia. The Senate of France (upper house of the Parliament) by overwhelming majority of votes (302 against 16) adopted a resolution calling for the gradual easing of sanctions against Russia in parallel with the implementation of the "Minsk agreements". The National Assembly of France (lower house) also called for the lifting of sanctions against Russia. Right-wing forces in other European countries also demand to establish relations with Russia and remove anti-Russian restrictions. Among them is the third most influential party in the Netherlands - the right-wing Freedom Party [9: 269].

The policy of sanctions is discussed at political and economic forums and scientific conferences, and various papers are published on this issue. The report of Professor P. Stykov at the University of Munich in January 2016 is devoted to the subject of sanctions. "Westliche Sanktionen gegen Russland" Eigentor von historischem Ausmaß "oder effektives Mittel zur Durchsetzung des Minsker Friedensplans?" / Western sanctions against Russia "Goal into own goal of a historical scale", or an effective means of implementing the Minsk peace plan? ([14]). "Goal into own goal" means the damage caused by the sanctions to the economy of Europe itself. The former president of the European Commission R. Prodi also spoke negatively about the impact of sanctions on the Italian economy: Das russische Bruttoinlandsprodukt wird in diesem Jahr um etwa 5\% sinken, was in Italien zu einem Einbruch der italienischen Exporte nach Russland um 50\% führen wird / This year the Gross Domestic Product of Russia will decrease by 5\%, which will lead to the collapse of Italian exports to Russia by 50\%. R. Prodi expressed his conviction that the sanctions were asymmetric (... dass die Sanktionen asymmetrisch waren 
...), since the US exports to Russia are growing, which cannot be said about the European exports ([15]). In July 2015, the following news was published on the portal "Deutsche Wirtschaftsnachrichten": Die Sanktionen gegen Russland nehmen für die deutsche Wirtschaft verheerende Ausmaße an / Sanctions against Russia are taking a devastating scale for the German economy. The news was published under the heading "Kalter Krieg" I Cold War ([16]).

On the streets of Germany in the pre-election campaign of 2016 one could see posters with the slogan Für unser Land und unsere Kinder. Wirtschaft unterstützen. Russlandsanktionen aufheben / For our Land and our children. Maintain the economy. Lift sanctions against Russia! On the posters of the conservative and euro-sceptic political party, "Alternative für Deutschland", there are constant demands for the lifting of sanctions against Russia. Representatives of this populist party point to the damage that was inflicted to the land of Mecklenburg-Western Pomerania, which manifested itself in the bankruptcy of some firms and in the loss of jobs. In this connection, it is emphasized that sanctions aimed at Russia should be lifted. The party "Alternative for Germany" (the second largest in the Land Parliament) believes that Europe should reach out first to settle conflicts with Russia. Today, according to the members of this party, the lifting of anti-Russian sanctions is a necessary condition for a prosperous future on the north of Germany [9: 269].

Professor U. Ludwig of the University of Leipzig answered positively to the question: Do the EU sanctions harm more to the European Union itself than sanctions from the Russian side? According to him, the reason for this is that the engineering industry primarily affects the German economy, rather than the producers of agricultural products. The professor doubts that political goals can be achieved by economic sanctions [17]. Sanctions against Russia cost billions to the economy of the European Union, and some politicians doubt their feasibility. So, the former Chairman of the EU Council R. Fico from Slovakia called them unsinnig - meaningless [18]. As for America, the toughening of sanctions in 2017 is explained, allegedly by Russia's interference in the election of the President D. Trump. The US Congress forced him to sign a decision on a new package of sanctions against Russia ([19]). The sanctions of America forced Russia to take countermeasures, which aroused criticism of the SPD members, who called them a violation of international law. The newspaper "Der Tagesspiegel" explains the reason for such indignation: American sanctions can also affect German firms involved in the Russian project for the construction of the Nord Stream 2 pipeline [20]. The policy of double standards is obvious. When sanctions affect Russia, representatives of the alliance's power structures actively or silently express support for such decisions. As soon as Russia takes retaliatory measures, a flurry of criticism hits the country.

The US administration adheres to the chosen political course. Speaking as a judge of the world, it declares: Diese Sanktionen sind nicht gegen das russische Volk gerichtet. Wir wollen ein besseres Verhältnis zu Russland, das geht nur durch eine Verhaltensänderung Moskaus / The sanctions are not directed against the Russian people. We want a better attitude towards Russia; this is possible only if Moscow's attitude changes [21].

From the above, we can conclude that the sanctions are, first of all, of the political character. Both the Crimea and Ukraine only serve as an excuse to exert pressure on the current Russian leader V. Putin, who demonstrates a firm character and unbending will in upholding the interests of his country, offering the EU and the US negotiations on resolving the crisis of political relations on a parity basis with a view to eliminate confrontation. Meanwhile, sanctions against the Russian Federation remain in force. The appeal "It is impossible to confuse politics and economics", none of the leaders of Western countries persistently notices [22]. In the German media, concerning the readiness of the Russian President to find a constructive solution, the phrase "aber das kann natürlich keine Einbahnstraße sein" / / this should not be, of course, a one-way street is quoted. The 
metaphor of the President is understandable. Any negotiations and relations should be built on a parity basis, not be tolerated and not be imposed on the other side [23]. Unprecedented pressure on Russia through sanctions does not bring the desired results to those parties that initiated and continue this policy. The results of the election of the President of the Russian Federation, which demonstrated the solidarity of the overwhelming majority of Russians in supporting the current course of the country's leadership, are the proof of this. In the situation of information war, the Russian media strongly support the patriotic sentiments and loyalty of politically indifferent people. The Russians are not inclined to blame their own government for the inconvenience. On the contrary, under the influence of external threats, there is concentration around the "center of power" - the authorities. In Germany, on the contrary, because of the apparent failures of the country's leadership, there has been an increase in discontent with the policy of the cabinet of A. Merkel, whose elections for the post of Chancellor were held under the auspices of political compromises with the growing new movements (for example, the "Alternative for Germany" that for the first time received $12.6 \%$ of the votes in the parliamentary elections and took the third place - 94 of the 709 parliamentary mandates). Thus, in the period from 2014 to 2018 , the anti-Russian sanctions led to the results directly opposite those that were expected by their authors.

\section{References}

1. S. Fischer, EU-Sanktionen gegen Russland Ziele, Wirkung und weiterer Umgang (https://www.swp-berlin.org/fileadmin/contents/products/aktuell/2015A26_fhs.pdf, 2015)

2. E. A. Morozov, N. R. Urazaeva, Contemporary Russia in the media sphere of Germany: linguistic policy analysis (Nosov Magnitogorsk State Technical University, Magnitogorsk, 2017)

3. Sanktionen gegen Russland für sechs weitere Monate (https://www.tagesschau.de /wirtschaft/russland-sanktionen-119.html, 2015)

4. Wir hätten uns mehr Mut gewünscht (http://www.ost-ausschuss.de/node/1035, 2015)

5. Kuzbass "PATRIOTS" took part in the rally "For decent work in the world and without sanctions!" (http://patriot-rus.ru/news/glavnyie-novosti/kuzbasskie-patriotyiprinyali-uchastie-v-mitinge-za-dostojnyij-trud-v-mire-i-bez-sankczij.html, 2014)

6. R. Thagushev, A. Bragin, Bulletin of Organizational, Party and Personnel Work, 10, 254 (2015)

7. Peace, labor, May! Ukraine over the edge (https://www.gazeta.ru/politics/2015 /04/30_a_6661833.shtml, 2015)

8. Mass CPRF action at the Theater in support of the reunification of the Crimea with Russia, against sanctions and in defense of the Russian Southeast of Ukraine (https://kprf.ru/photoreports/192.html, 2014)

9. C. G. Shulezhkova, Give the world a chance! Dictionary of modern political slogans of Russia and Germany (Magnitogorsk Printing House, Magnitogorsk, 2016)

10. N. Andreev, Sanctions do not kill us, but make stronger (https://www.chel.kp.ru/ daily/26596/3612217, 2016)

11. Interview to the Internet portal "Regions Online" by A. Maslennikov, the Director of the Department of Economic Development of the Ministry of Economic Development of the Russian Federation, 18.07.2017 (https://www.gosrf.ru/news/31325, 2017) 
12. EU-Sanktionen gegen Russland aufgrund der Krise in der Ukraine (https://europa.eu/ newsroom/highlights/special-coverage/eu-sanctions-against-russia-over-ukrainecrisis_de, 2018)

13. V. Laru, A. Khalitov, Germany lost more than 42 thousand jobs due to sanctions (https://iz.ru/671316/dmitrii-laru-anna-khalitova/germaniia-poteriala-iz-za-sanktciibolee-42-tys-rabochikh-mest, 2017).

14. P. Stykow, Westliche Sanktionen gegen Russland „Eigentor von historischem Ausmaß" oder effektives Mittel zur Durchsetzung des Minsker Friedensplans? (https://www.

petrakellystiftung.de/fileadmin/user_upload/newsartikel/PDF_Dokus/Wen_treffen_Sa nktionen_-_Prof._Dr._Petra_Stykow_-_Westliche_Sanktionen_gegen_Russland__Eigentor_von_historischem_Ausmass_oder_effektives_Mittel_zur_Durchsetzung_de s_Minsker_Friedensplans.pdf, 2016)

15. Prodi: Italiens Exporte brechen wegen Russland-Sanktionen ein (http://deutschewirtschafts-nachrichten.de/2015/01/05/prodi-italiens-exporte-brechen-wegenrussland-sanktionen-ein, 2015)

16. Sanktionen gegen Russland: Schwerer Schaden für deutsche Wirtschaft (https://deutsche-wirtschafts-nachrichten.de/2015/07/23/deutsche-exporte-nachrussland-brechen-um-34-prozent-ein, 2015)

17. Neue Studie: Milliardenschaden für deutsche Wirtschaft durch Russland-Sanktionen (https://de.sputniknews.com/wirtschaft/20161123313479220-milliardenschadendeutsche-wirtschaft-russland-sanktionen, 2016).

18. EU-Sanktionen gegen Russland werden verlängert (www.rponline.de/politik/ausland/eu-sanktionen-gegen-russland-werden-bis-mitte-2017verlaengert-aid-1.6468048, 2016).

19. USA verhängen Sanktionen gegen 39 russische Firmen (https://www.zeit.de/politik/ausland/2017-10/russland-sanktionen-usa-listeunternehmen, 2017)

20. A. Meier, Wird Deutschland in einen Handelskrieg hineingezogen? https://www.tagesspiegel.de/politik/us-sanktionen-gegen-russland-wird-deutschlandin-einen-handelskrieg-hineingezogen/20129698.html, 2017)

21. USA verhängen Sanktionen gegen russische Oligarchen, (https://www.tagesspiegel.de/politik/streit-mit-russland-usa-verhaengen-sanktionengegen-russische-oligarchen/21149278.html, 2018)

22. Sanctions against Russia: consolidation of vs. self-isolation (http://pravoedelo.ru /news/read/148, 2014)

23. EU verlängert Krim-Sanktionen (https://www.zeit.de/politik/ausland/2016-06/ ukraine-krise-russland-eu-krim-sanktionen-verlaengerung, 2016) 